\title{
STRATEGI MENINGKATKAN PARTISIPASI MASYARAKAT DALAM PILKADA SERENTAK 2020 DI MASA PANDEMI COVID-19
}

\section{SALSABILA YUMNA FADHILA, ${ }^{1}$ DEWI EROWATI ${ }^{2}$}

Program Studi IImu Pemerintahan, Fakultas IImu Sosial dan IImu Politik, Universitas Diponegoro

yumnabela733@gmail.com¹dewi.erowati@live.undip.ac.id ${ }^{2}$

\section{Abstract}

This article will discuss the covid-19 pandemic has become one of the most serious problems in holding the 2020 simultaneous regional elections. These conditions have the potential to reduce voter turnout, therefore the strategy to increase public participation needs to be implemented even more strongly. In the 2020 simultaneous regional elections, the KPU has set a national voter turnout target of $77.5 \%$. As an effort to achieve this target, the KPU has implemented a strategy to increase public participation as voters. Qualitative methods are used in this article, and data collection techniques are used through interviews with Head of the Technical and Public Relation Subdivision of the General Election Commissin of Central Java, Dimas Dwihangga Narotama, S.IP and documentation. The results and discussion revealed that the KPU implemented a strategy of maximizing socialization through social and virtual media by holding webinars. However, in-person or face-to-face socialization is still carried out by reducing the number of activities and participants and still paying attention to health protocols. The implementation of strategies through social media or online is more dominant in efforts to increase community participation carried out by each Regency / City KPU in Central Java in the 2020 simultaneous regional elections.

Key Words: simultaneous regional elections; covid-19 pandemic; strategy; participation

POLITEA : Jurnal Politik Islam

Vol. 4 No.1Januari-Juni 2021
SALSABILA Y.F., DEWI EROWATI

Strategi Meningkatkan Partisipasi.. 


\section{A. PENDAHULUAN}

Pemilihan Umum (Pemilu) adalah pilar demokrasi Indonesia, merupakan sarana untuk mewujudkan kedaulatan rakyat yang berguna untuk menghasilkan pemerintahan yang demokratis. Pemilu diharapkan menghasilkan pemerintahan yang memiliki legitimasi yang kuat dan amanah. Pemilu menjadi salah satu tonggak tegaknya demokrasi karena dalam hal ini rakyat dapat secara langsung ikut terlibat aktif memilih dan menentukan arah kebijakan politik negara dalam satu periode pemerintahan ke depannya. Pemilihan Kepala Daerah atau sering dikenal dengan Pilkada, masuk ke dalam rezim Pemilu sejak berlakukannya Undang-Undang Nomor 32 Tahun 2004 tentang Pemerintahan Daerah, yang mana seorang Kepala Daerah dipilih secara langsung oleh rakyat.

Pesta demokrasi Pemilihan Kepala Daerah (Pilkada) serentak di Indonesia diselenggarakan pada 9 Desember 2020. Kegiatan Pilkada tersebut rutin diselenggarakan setiap lima tahun sekali. Namun, pada Pilkada tahun 2020 ini berbeda dengan tahun-tahun sebelumnya. Hal ini karena pada Pilkada tahun 2020 diselenggarakan di tengah pandemi Covid-19 dimana pemerintah mengeluarkan aturan untuk melaksanakan social distancing dan physical distancing. Sementara itu, penyelenggaraan Pilkada tidak terlepas dari adanya pengumpulan massa, mulai dari tahapan penyusunan daftar pemilih, pencocokan data pemilih, penetapan bakal pasangan calon, kampanye, pemungutan suara, sampai dengan perhitungan suara. Hal ini juga berimplikasi dengan peserta pasangan calon untuk melakukan kampanye yang identik dengan mobilisasi politik agar mendapatkan dukungan pemilih untuk mendapatkan suara terbanyak 
(Hergianasari, 2016:249).

Oleh karena itu, untuk menyikapi hal tersebut pemerintah sepakat menunda penyelenggaraan Pemilihan Kepala Daerah 2020. Pilihan penundaan penyelenggaraan Pilkada yaitu 9 Desember 2020, 17 Maret 2021 dan 29 Desember 2021. Pemerintah kemudian menetapkan penyelenggaraan Pilkada melalui PP Nomor 2 Tahun 2020 dimana tanggal 9 Desember 2020 ditetapkan sebagai tanggal pelaksanaan Pilkada 2020. Penetapan tanggal tersebut menimbulkan pro-kontra publik karena di Indonesia pada bulan Agustus 2020 grafik kasus positif Covid-19 belum menunjukkan adanya penurunan. (Infografis COVID-19 (1 September 2020) - Berita Terkini | Gugus Tugas Percepatan Penanganan COVID-19, n.d.)

Dengan ditetapkannya penyelenggaraan Pilkada pada bulan Desember 2020, Jawa Tengah merupakan salah satu provinsi yang ikut dalam pelaksanaan Pilkada serentak 2020. Berdasarkan data KPU, angka partisipasi pemilih di Jawa Tengah sebelum adanya pandemi Covid-19 dalam Pemilu cukup tinggi yaitu mencapai $78,88 \%$ melampaui target KPU Jawa Tengah $77,5 \%$. Hal ini menjadi pekerjaan rumah yang cukup berat bagi KPU agar angka partisipasi pemilih tersebut dapat dipertahankan bahkan ditingkatkan di Pilkada 2020 walaupun pelaksanaannya di tengah masa pandemi. KPU Jawa Tengah memiliki target partisipasi pemilih dalam Pilkada serentak 2020 ini sebesar 77,85\%.

Permasalahan yang kemudian muncul yaitu ancaman terhadap keselamatan jiwa dan kesehatan masyarakat jika Pilkada 2020 tetap 
dilaksanakan, hal ini sangat beresiko bagi masyarakat sebagai konstituen, peserta yaitu pasangan calon dan penyelenggara Pilkada yaitu KPU dan tim penyelenggara Pilkada. (Hergianasari, 2020:112-121) Bukan hanya itu, kualitas dari tahapan penyelenggaraan yang dilakukan di tengah pandemi Covid-19 berpotensi menimbulkan penurunan, adanya penurunan partisipasi masyarakat untuk datang ke Tempat Pemungutan Suara (TPS), serta partisipasi masyarakat sebagai relawan juga mengalami penurunan. Seringkali pemilih tampak berpandangan sempit dan tidak konsisten dalam melakukan pemilihan. (Sniderman \& Highton, 2011:185) Hal ini merupakan tantangan demokrasi Indonesia. Tantangan demokrasi tersebut lebih parah ditambah dengan terjadinya pandemi global Covid-19 yang mana pelaksanaan Pilkada serentak 2020 harus dengan menerapkan protokol kesehatan yaitu social distancing dan physical distancing. Di masa pandemi seperti ini partisipasi masyarakat diprediksikan mengalami penurunan dalam menggunakan hak pilih karena masih tingginya jumlah kasus Covid-19 yang terjadi dan pelaksanaan pemungutan suara di bulan Desember bertepatan dengan musim penghujan yang mana faktor cuaca di bulan ini cenderung tidak mendukung sehingga dapat menjadi alasan masyarakat untuk tidak hadir di TPS pada hari (Inggried \& Dewi, 2020 : 168). Padahal, Partisipasi politik masyarakat sangat menentukan keberhasilan penyelenggaraan Pilkada serentak 2020. Berdasarkan permasalahan-permasalahan tersebut di atas maka pentingnya strategi untuk meningkatkan partisipasi masyarakat pemilih dalam Pilkada masa pandemic Covid-19 ini perlu dilakukan untuk memberikan pemahaman dan pendidikan politik pentingnya menjaga demokrasi di tengah pandemi 
Covid-19.

Pentingnya strategi untuk meningkatkan partisipasi masyarakat dari KPU sebagai penyelenggara Pilkada ini dilakukan untuk memberikan pemahaman, mendiskusikan, dan mensosialisasikan berbagai pengetahuan yang berkaitan dengan pelaksanaan Pilkada 2020 di tengah pandemi Covid-19 yang mana harus tetap dilaksanakan untuk menjaga kesinambungan demokrasi pada pemerintahan lokal. Selain itu, pentingnya strategi peningkatan ini dilakukan untuk menjaga angka partisipasi politik masyarakat agar tidak menurun secara drastis sebagai dampak Pilkada di masa pandemi Covid-19. Keterlibatan dan keaktifan masyarakat dalam berpartisipasi pada proses Pemilihan Kepala Daerah baik sebagai pengguna hak pilih, melaksanakan pendidikan politik kepada sesama, turut membantu pengawasan pelaksanaan Pilkada, dan lainnya. Hal ini merupakan bentuk kontrol dari masyarakat dalam mengawal Pilkada dan menjaga kedaulatan rakyat. Akan tetapi pada pelaksanaannya di Pilkada 2020 mengalami hal yang jauh berbeda karena adanya pandemi Covid-19. Larangan kegiatan yang berkaitan dengan pengumpulan massa atau kerumunan massa tercantum dalam Maklumat Kapolri Nomor Mak/2/III/2020 diterbitkan pada 19 Maret 2020 dan dicabut dengan Surat Telegram Rahasia (TR) Kapolri Jendral Idham Azis nomor STR/364/VI/OPS.2/2020 kemudian hal ini dijadikan pedoman Komisi Pemilihan Umum sebagai penyelenggara untuk mengubah kegiatan yang awalnya tidak memperbolehkan kegiatan yang berpotensi menimbulkan kerumunan massa menjadi dibatalkan dan diubah dengan kegiatan yang baru yang memungkinkan mengadakan kegiatan akan tetapi dengan 
melaksanakan protokol kesehatan Covid-19. Hal tersebut merupakan tantangan bagi penyelenggara Pilkada untuk dalam melaksanakan setiap tahapan pelaksanaan Pilkada.

Dari uraian di atas, dapat diketahui bahwa salah satu peran strategis Komisi Pemilihan Umum sebagai penyelenggara Pilkada adalah meningkatkan kesadaran politik masyarakat untuk berperan aktif dan berpartisipasi dalam proses Pilkada 2020. Dengan demikian, lembaga Komisi Pemilihan Umum memerlukan upaya sistematis dalam mengambil strategi yang tepat untuk meningkatkan partisipasi masyarakat di tengah masa pandemi Covid-19. Oleh karena itu, dapat ditarik rumusan permasalahan dalam artikel ini yaitu bagaimana strategi Komisi Pemilihan Umum dalam upayanya untuk meningkatkan partisipasi masyarakat dalam Pilkada Serentak 2020 di masa pandemi Covid-19?

\section{B. METODOLOGI}

Artikel ini menggunakan metode penelitian kualitatif. Penelitian kualitatif menurut Denzim dan Lincol (Moleong, 2010:5) adalah penelitian yang menggunakan latar belakang alamiah dengan maksud menjelaskan fenomena yang terjadi dan dilakukan dengan jalan melibatkan berbagai metode yang ada. Metode penelitian kualitatif dipilih karena lebih menekankan pada kedalaman data dan penjelasan, dengan menggunakan teknik pengumpulan data yang dilakukan melalui wawancara dengan Kasubbag Teknis dan Hubmas KPU Provinsi Jawa Tengah, Dimas Dwihangga Narotama, S.IP dan dokumentasi. Sumber data berasal dari data primer dilaksanakan melalui wawancara dan data sekunderberupa 
literatur-literatur serta dokumen-dokumen yang berkaitan dengan kegiatan strategi meningkatkan partisipasi masyarakat yang dilaksanakan Komisi Pemilihan Umum. Sumber informasi dari media online juga dijadikan sebagai referensi pada artikel ini. Data yang diperoleh kemudian dipilih dan diseleksi dengan hanya mencantumkan referensi yang relevan untuk menjawab rumusan masalah pada artikel ini.

\section{PEMBAHASAN}

1. Analisis SWOT Faktor Internal dan Eksternal Komisi Pemilihan Umum Analisis faktor internal dan ekstenal menghasilkan keuntungan bagi KPU Jawa Tengah. Analisis faktor internal dan eksternal memberikan data tentang perkembangan dan pencapaian suatu organisasi. Organisasi harus memiliki informasi yang memadai tentang kualitas dan kekurangannya sesuai dengan peluang dan bahaya yang mereka hadapi. Setelah dilakukan analisis faktor internal dan eksternal, KPU Jawa Tengah memiliki faktor internal dan eksternal yang akan berdampak pada pengambilan strategi untuk meningkatkan partisipasi masyarakat pada Pilkada serentak 2020 di tengah masa pandemi covid-19. Kasubbag Teknis dan Hubungan Masyarakat KPU Provinsi Jawa Tengah mengatakan :

"Pilkada 2020 memang menjadi tantangan sendiri untuk kami sebagai penyelenggara Pemilu dengan kondisi pandemi seperti ini dengan target nasional $77,5 \%$ ya meskipun tiap kabupaten/kota memiliki target tersendiri saya tidak hafal datanya nanti saya kirim ya.Kondisi ini membuat masyarakat cenderung malas untuk pergi 
ke TPS karena khawatir akan tertular virus, apalagi tingkat pendidikan politik masyarakat masih rendah dan masyarakat belum begitu peka terhadap hak politiknya sehingga kepedulian terhadap pentingnya Pemilu ini masih kurang lebih parahnya mbak zaman sekarang berita-berita hoax cepat sekali tersebar ini memperkeruh suasana. Ancaman-ancaman seperti ini yang menjadi PR bagi KPU untuk mencari strategi agar hal ini tidak berdampak lebih buruk lagi terhadap pelaksanaan Pilkada 2020. Strateginya lebih memaksimalkan sosialisasi lewat medoso dan virtual (webinar) namun sosialisasi tatap muka tetap dilaksanakan dengan mengurangi jumlah kegiatan dan peserta. Sosialisasi ini dilakukan berjenjang sampai tingkat RT, setidaknya dengan cara seperti itu semestinya setiap kepala keluarga mendapatkan informasi tentang pemilihan ini. Kegiatan-kegiatan sebagai bentuk upaya strategi peningkatan partisipasi masyarakat ini sudah banyak dilaksanakan di kabupaten-kabupaten/kota, memang disini posisi KPU Jawa Tengah hanya berperan dalam sosialisasi kulit terluarnya saja, sementara kegiatan tersebut diimplementasikan secara langsung oleh KPU Kabupaten/Kota karena dalam lembaga KPU dari tingkat pusat hingga kabupaten/kota memiliki peran masing-masing. Pelaksanaan strategi dengan sosialisasi ini cukup bisa diandalkan karena adanya kerja sama lintas departemanatau instansi yang berjalan baik, terdapat bantuan perangkatkelembagaan hingga tingkat desa/kelurahan serta adanya kerjasama yang baik antara komisioner maupun anggota KPU Jawa Tengah, KPU Kab/Kota, hingga PPK, PPS, danKPPS ditambah dengan kemampuan pihak yang terlibat dalam mengoperasikan teknologi informasi dankomunikasi dengan 
baik.UU yang mendukung penyelenggaraan PemilihanUmum di masa pandemi covid-19 ini juga sangat berperan sebagai pedoman kami dalam bergerak. Lalu, sekarang ini juga banyak organisasi yang terlibat dalam sosialisasi Pemilu sehingga kami merasa sangat terbantu. Media cetak, media elektronik, dan media sosial juga mampu menyebar luaskan informasi secara massif serta banyak juga event virtual yang diselenggarakan dalam rangka Pilkada 2020 ini. Pilkada di tengah pandemi covid ini tentu memiliki kelamahan, misalnya saja saat akan sosialisasi kita untuk turun lapangan ada batas-batasnya tidak seleluasa seperti biasanya jadi susah menyentuh semua lapisan masyarakat apalagi kasus di Jawa Tengah meningkat, anggaran yang dialokasikan juga mepet, dan jadwal yang ada tidak fleksibel karena rundown sudah dibuat."

Faktor kekuatan, kelemahan, tantangan, serta peluang yang ada tersebut dapat dilihat pada tabel berikut: 
Tabel 1. Analisis Faktor-faktor Internal dan Eksternal KPU Jawa Tengah

\begin{tabular}{|c|c|}
\hline $\begin{array}{l}\text { Kekuatan } \\
\text { (Strengths) }\end{array}$ & \\
\hline 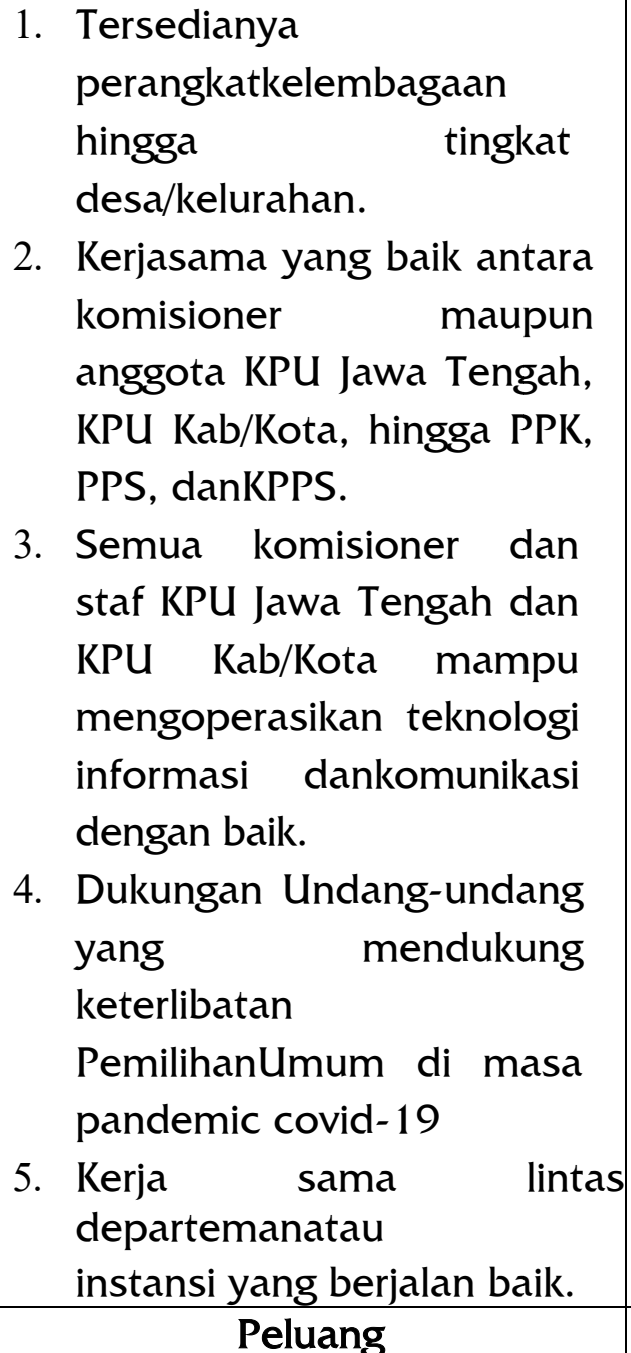 & $\begin{array}{l}\text { 1. Akses terjun lapangan yang } \\
\text { terbatas di masa pandemi } \\
\text { covid-19. } \\
\text { 2. Anggaran yang terbatas. } \\
\text { 3. Sosialisasi yang sulit } \\
\text { menjangkau seluruh lapisan } \\
\text { masyarakat. } \\
\text { 4. Jadwal yang sudah } \\
\text { ditetapkan } \\
\text { fleksibeldiubah. tidakbisa } \\
\text { 5. Persebaran covid-19 yang } \\
\text { meningkat di wilayahJawa } \\
\text { Tengah }\end{array}$ \\
\hline
\end{tabular}




\begin{tabular}{|c|c|}
\hline (Opportunities) & (Threats) \\
\hline 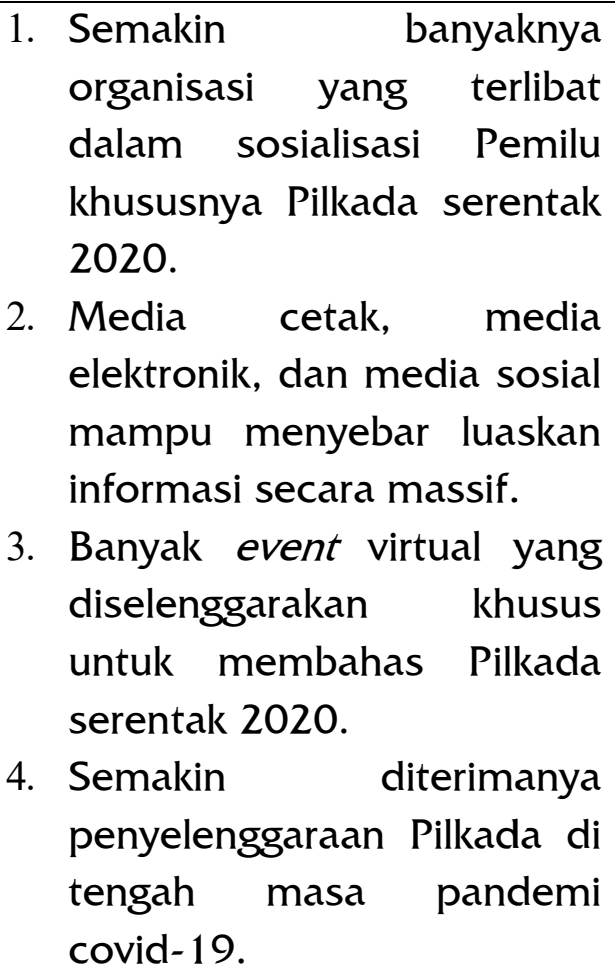 & $\begin{array}{l}\text { 1. Tingkat pendidikan politik } \\
\text { masyarakat yang masih } \\
\text { rendah. } \\
\text { 2. Masyarakat belum peka } \\
\text { terhadap hak politiknya. } \\
\text { 3. Banyaknya berita yang } \\
\text { menyesatkan } \\
\text { mediasosial. } \\
\text { 4. Di masa } \\
\text { kepedulian } \\
\text { masyarakat terhadap Pilkada } \\
\text { masih kurang. } \\
\text { 5. Kekhawatiran masyarakat } \\
\text { akan adanya penyebaran } \\
\text { covid-19 di TPS. }\end{array}$ \\
\hline
\end{tabular}

Sumber: data diolah

Dari tabel di atas, dapat dibuat model analisis SWOT strategi KPU dalam meningkatkan partisipasi masyarakat dalam Pilkada serentak 2020 di tengah masa pandemi covid-19.

Tabel 1.2 Analisis SWOT strategi peningkatkan partisipasi masyarakat dalam Pilkada serentak 2020 di masa pandemi covid-19 


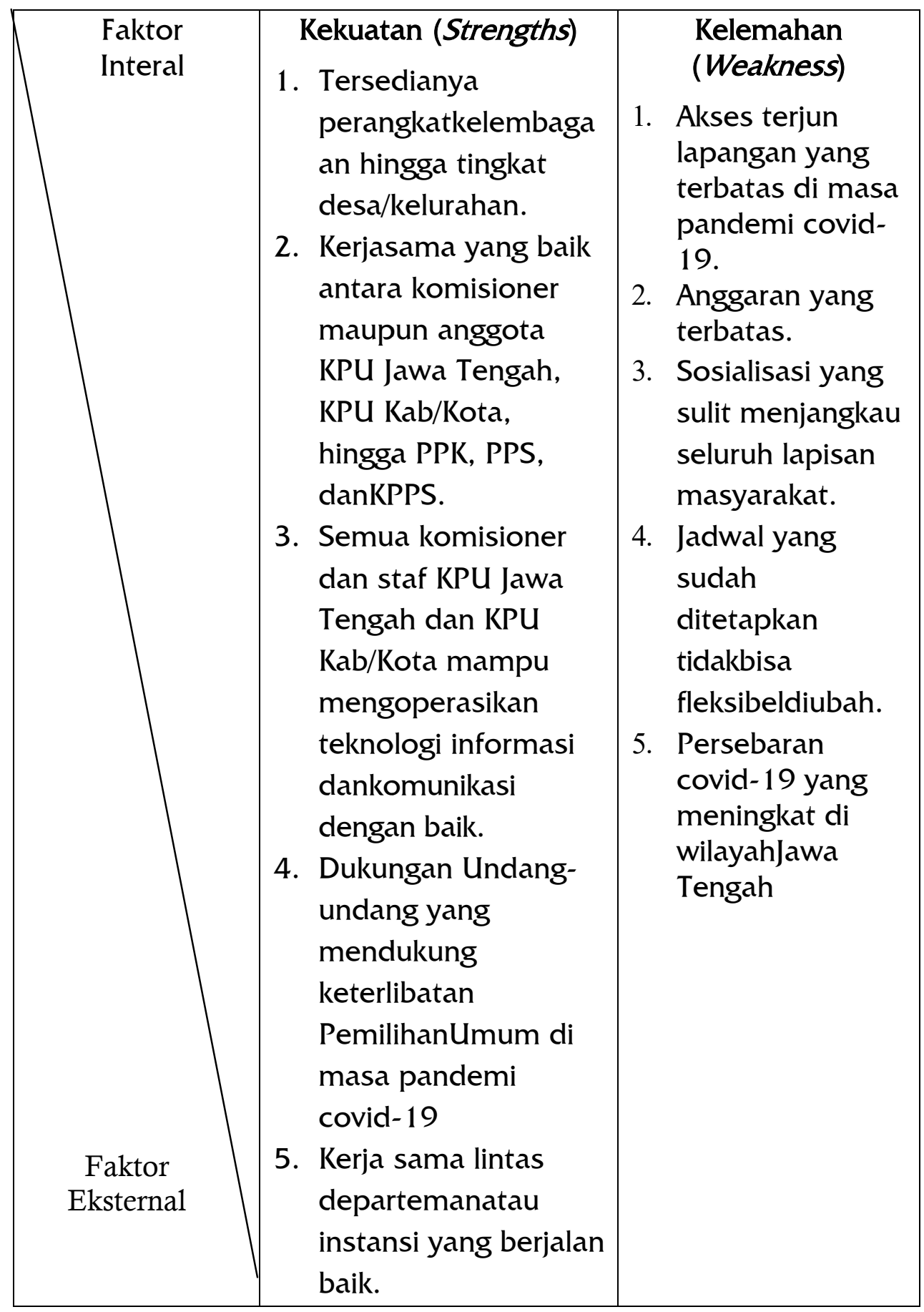




\begin{tabular}{|c|c|c|}
\hline $\begin{array}{l}\text { Peluang } \\
\text { (Opportunities) } \\
\text { l. Semakin } \\
\text { banyaknya } \\
\text { organisasi } \\
\text { yang terlibat } \\
\text { dalam } \\
\text { sosialisasi } \\
\text { Pemilu } \\
\text { khususnya } \\
\text { Pilkada } \\
\text { serentak } \\
\text { 2020. } \\
\text { Media cetak, } \\
\text { elektronik, } \\
\text { dan media } \\
\text { sosial } \\
\text { mampu } \\
\text { menyebarka } \\
\text { n informasi } \\
\text { secara } \\
\text { masif. } \\
\text { Banyak even } \\
\text { virtual yang } \\
\text { dilaksanakan } \\
\text { khusus } \\
\text { untuk } \\
\text { membahas } \\
\text { Pilkada. } \\
\text { diterimanya } \\
\text { penyelengga } \\
\text { raan Pilkada }\end{array}$ & $\begin{array}{c}\text { STRATEGI S-O } \\
\text { Memperkuat } \\
\text { kelembagaan KPU } \\
\text { melalui peningkatan } \\
\text { kemampuan } \\
\text { KPUKab/Kota dan PPS, } \\
\text { PPK, KPPS serta } \\
\text { memanfaatkan media } \\
\text { massa dan media sosial } \\
\text { dalam mensosialisasikan } \\
\text { tahapan-tahapan Pilkada } \\
\text { di masa pandemi covid- } \\
19\end{array}$ & $\begin{array}{c}\text { STRATEGI W-O } \\
\text { Melaksanakan } \\
\text { sosialisasi } \\
\text { pelaksanaan } \\
\text { Pilkada melalui } \\
\text { kerja sama dengan } \\
\text { organisasi- } \\
\text { organisasi } \\
\text { kemasyarakatan } \\
\text { hingga tingkat } \\
\text { RT/RW }\end{array}$ \\
\hline
\end{tabular}




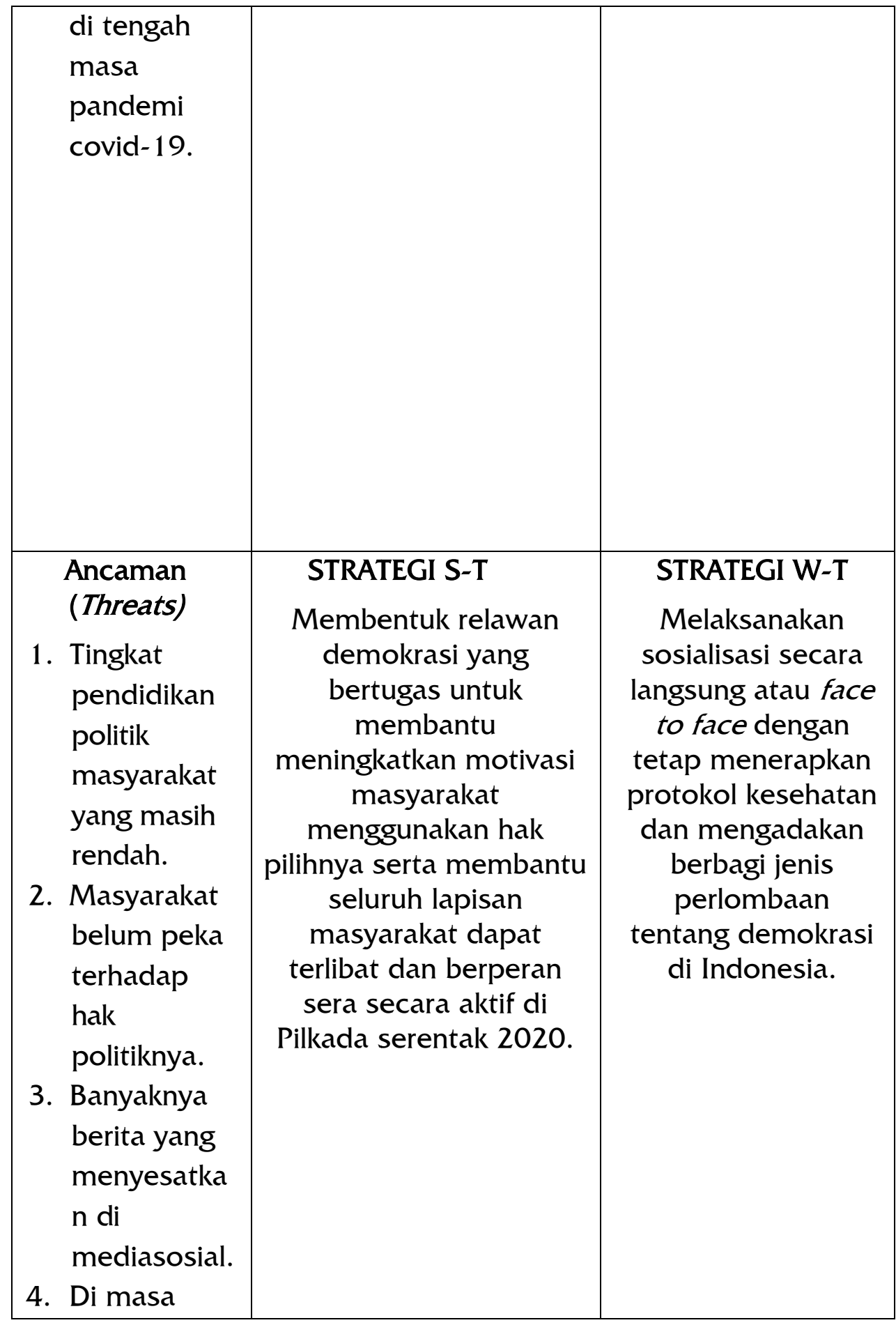




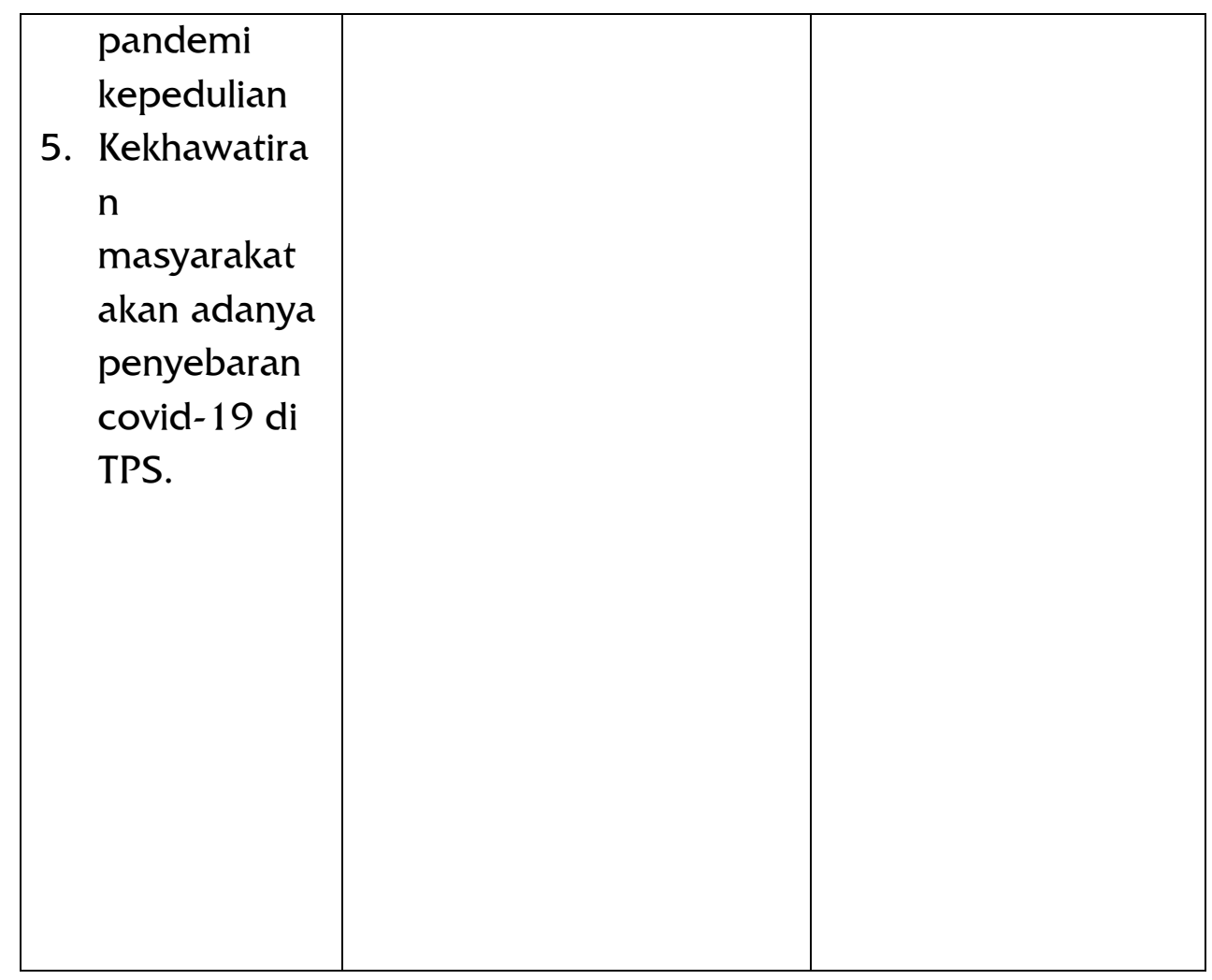

\section{Sumber : data diolah}

Berdasarkan tabel data analisis SWOT strategi peningkatan partisipasi masyarakat yang dilakukan KPU Jawa Tengah beserta KPU Kabupaten/Kota dalam Pilkada serentak 2020. Hasil analisis strategi menggunakan SWOT sebagai berikut:

Strategi S-O berasal dari kekuatan (Strenghts) dan peluang (Opportunities) yang dimiliki suatu asosiasi/organisasi. Strategi S-O diselesaikan dengan memanfaatkan kekuatan asosiasi untuk memanfaatkan peluang yang dimilikinya. Strategi S-O dalam situasi ini adalah strategi yang mendukung orientasi kebijakan strategi. Strategi S-O yang diambil adalah memperkuat kelembagaan KPU melalui peningkatan kemampuan KPUKab/Kota dan PPS, PPK, KPPS 
serta memanfaatkan media massa dan media sosial dalam mensosialisasikan tahapan-tahapan Pilkada di masa pandemi covid19

Strategi S-T ini bersumber dari kekuatan (Strenghts) dan ancaman (Threats) yang mana merupakan strategi yang dibuat berdasarkan kekuatan asosiasi yang berasal dari faktor internal yang berfungsi untuk menghadapi ancaman berasal dari lingkungan luar. Untuk meningkatkan partisipasi masyarakat dalam Pilkada serentak 2020 di masa pandemic covid-19, strategi S-T yang diambil KPU Jawa Tengah adalah membentuk relawan demokrasi yang bertugas untuk membantu meningkatkan motivasi masyarakat menggunakan hak pilihnya serta membantu seluruh lapisan masyarakat dapat terlibat dan berperan sera secara aktif di Pilkada serentak 2020.

Strategi W-O merupakan strategi yang bersumber dari adanya kelamahan (Weakness) dan peluang (Opportunities), ini merupakan sebuah strategi yang dibuat dengan menekan kelemahan yang dimiliki asosiasi untuk memanfaatkan peluang yang ada sebesar-besarnya. Strategi W-O merupakan strategi yang mendukung pelaksanaan strategi putar balik, hal ini memiliki arti bahwa asosiasi harus mengambil langkah strategis untuk mengatasi berbagai kelemahan yang dimiliki agar asosiasi tersebut dapat memanfaatkan peluang yang ada secara optimal. Strategi W-O yang dibuat untuk meningkatkan partisipasi masyarakat dalam Pilkada serentak 2020 di masa pandemi covid-19 adalah dengan melaksanakan sosialisasi pelaksanaan Pilkada melalui kerja sama 
dengan organisasi-organisasi kemasyarakatan hingga tingkat RT/RW

Strategi W-T merupakan strategi yang berasal dari kelemahan (Weakness) dan ancaman (Threats) yang dimiliki sebuah asosiasi atau organisasi, hal ini merupakan strategi khusus yang dibuat melalui cara meminimalisasi kelemahan yang ada dan menghindari ancaman-ancaman yang berasal dari luar. Hal tersebut merupakan suatu kondisi yang tidak menguntungkan karena aosisai sedang mengalami ancaman dari luar dan memiliki kelemahan dari faktor internal. Strategi yang mendukung strategi W-T adalah strategi yang dilaksankaan dengan tindakan-tindakan bersifat inovatif. Strategi yang diambil adalah melaksanakan sosialisasi secara langsung atau face to face dengan tetap menerapkan protokol kesehatan dan mengadakan berbagi jenis perlombaan tentang demokrasi di Indonesia.

\section{Strategi Meningkatkan Partisipasi Masyarakat dalam Pilkada}

\section{Serentak 2020 di Masa Pandemi Covid-19}

RUU Strategi yang dipilih Komisi Pemilihan Umum dalam melaksanakan upaya peningkatan partisipasi masyarakat dalam Pilkada serentak 2020 di tengah masa pandemi covid-19 yaitu memaksimalkan sosialisasi dengan menggunaan website, media sosial, dan media online milik KPU baik KPU RI, KPU Provinsi, ataupun KPU Kabupaten/Kota. Selain itu juga memaksimalkan penggunaan media sosial dan media online milik badan adhoc. Strategi lain yang dilaksanakan adalah dengan melibatkan 
Pemerintah Daerah, Bawaslu/Panwaslu, Partai Politik, Non Government Organization (NGO), Organisasi Masyarakat (Ormas), LSM, dan Media lainnya. Pembentukan relawan demokrasi juga sebagai salah satu strategi yang diterapkan dalam upayanya meningkatkan partisipasi masyarakat. Pembentukan relawan demokrasi tersebut dilaksanakan dengan cara merekrut influencer yang tetap mengedepankan aspek netralitas dalam Pilkada serentak 202. Dalam masa pandemi covid-19, KPU lebih mengedepankan sosialisasi dengan mengadakan kegiatan webinar dan diskusi secara daring dengan berbagai topik tentang kepemiluan. Selain itu, KPU menciptakan inovasi kegiatan sosialisasi untuk mengatasi keterbatasan anggaran serta memaksimalkan peran dan fungsi PPID (Pejabat Pengelola Informasi dan Dokumentasi) dan RPP (Rancangan Peraturan Pemerintah).

Strategi tersebut dilaksanakan agar Pilkada 2020 tetap berjalan dengan baik walaupun dalam keadaan pandemi. Sosialisasi Pilkada serentak 2020 itu sendiri dilaksanakan dengan tujuan antara lain, Pertama untuk meningkatkan pemahaman dan pengetahuan masyarakat akan pentingnya Pemilihan Umum dalam membangun kehidupan demokrasi lokal. Kedua, untuk meningkatkan pemahaman dan pengetahuan masyarakat tentang tahapan, program, jadwal, dan hasil Pilkada. Ketiga, meningkatkan pemahaman dan pengetahuan masyarakat tentang beberapa hal teknis dalam menggunakan hak politiknya dengan benar dalam Pilkada. Keempat, meningkatkan kesadaran masyarakat pemilih 
utuk berperan serta dalam setiap tahapan Pilkada. Kelima, untuk meningkatkan kesadaran dan partisipasi pemilih dalam menggunakan hak pilihnya pada Pilkada serta menolak segala bentuk Money Politic.

3. Upaya untuk Mencapai Target Partisipasi Masyarakat dalam Pilkada Serentak 2020 di Jawa Tengah

Pilkada serentak 2020 di tengah pandemi menggerakkan semua elemen Komisi Pemilihan Umum sebagai penyelenggara pemilu baik KPU RI, KPU Provinsi, maupun KPU Kabupaten/Kota untuk menggunakan strategi yang tepat guna meningkatkan partisipasi pemilih. Salah satu upayanya dengan menggencarkan sosialisasi. Sebelum melaksanakan sosialisasi, KPU membagi dan menentukan peran sosialisasi yang dilakukan oleh masing-masing tingkatan KPU. KPU RI dan Provinsi berperan dalam sosialisasi pada kulit luar saja sementara KPU Kabupaten/Kota lebih mendalam dan masif. Sosialisasi tersebut memiliki target yaitu tersebar luasnya informasi mengenai tahapan dan program penyelenggaraan Pilkada kepada masyarakat secara terpadu dengan mengikut sertakan pemangku kepentingan. Pemangku kepentingan dalam hal ini adalah Pemilih, baik pemilih pemula, pemilih perempuan, atau pun pemilih berkebutuhan khusus, Partai Politik, Penyelenggara termasuk Bawaslu/Panwaslu, Pemerintah, Pemantau, Organisasi Sosial Masyarakat, LSM, TNI/Polri, dan media. Sosialisasi Pilkada salah satunya dilaksanakan untuk memberikan informasi mengenai tahapan dan tata cara memberikan hak pilih di tengah pandemi dan 
mencapai target partisipasi masyarakat di masing-masing Kabupaten/Kota yang menyelenggarakan Pilkada serentak 2020.

Berikut data target partisipasi masyarakat di Jawa Tengah berdasarkan data KPU Jawa Tengah:

Tabel 3. Target Partisipasi Pemilih di Provinsi Jawa Tengah

\begin{tabular}{|c|l|c|}
\hline No. & \multicolumn{1}{|c|}{$\begin{array}{c}\text { Kabupaten/Kota Penyelenggara } \\
\text { Pilkada }\end{array}$} & Target Partisipasi (\%) \\
\hline 1 & KPU Kota Pekalongan & $77,5 \%$ \\
\hline 2 & KPU Kabupaten Pekalongan & $78 \%$ \\
\hline 3 & KPU Kota Semarang & $77,5 \%$ \\
\hline 4 & KPU Kabupaten Semarang & $77,5 \%$ \\
\hline 5 & KPU Kota Magelang & $80 \%$ \\
\hline 6 & KPU Kabupaten Kebumen & $77,5 \%$ \\
\hline 7 & KPU Kabupaten Rembang & $77,5 \%$ \\
\hline 8 & KPU Kota Surakarta & $77,5 \%$ \\
\hline 9 & KPU Kabupaten Purbalingga & $77,5 \%$ \\
\hline 10 & KPU Kabupaten Boyolali & $77 \%$ \\
\hline 11 & KPU Kabupaten Blora & $77,5 \%$ \\
\hline 12 & KPU Kabupaten Kendal & $77 \%$ \\
\hline 13 & KPU Kabupaten Sukoharjo & $77,5 \%$ \\
\hline 14 & KPU Kabupaten Wonosobo & $74 \%$ \\
\hline 15 & KPU Kabupaten Wonogiri & $\mathbf{8 5} \%$ \\
\hline 16 & KPU Kabupaten Purworejo & $77,5 \%$ \\
\hline 17 & KPU Kabupaten Sragen & $77,5 \%$ \\
\hline 18 & KPU Kabupaten Klaten & \\
\hline & & \\
\hline
\end{tabular}




\begin{tabular}{|c|l|c|}
\hline 19 & KPU Kabupaten Pemalang & $77,5 \%$ \\
\hline 20 & KPU Kabupaten Grobogan & $77,5 \%$ \\
\hline 21 & KPU Kabupaten Demak & $77,5 \%$ \\
\hline
\end{tabular}

Untuk mencapai target yang telah ditentukan, KPU Kabupaten/Kota di Jawa Tengah gencar melaksanakan strategi meningkatkan partisipasi masyarakat dalam Pilkada walaupun di tengah pandemi covid-19 baik secara langsung maupun virtual. Strategi yang dilakukan berbeda-beda dari kabupaten satu dengan lainnya. KPU Kota Pekalongan dengan terget partisipasi masyarakat 77,5\% dalam Pilkada 2020, melaksanakan strategi peningkatan partisipasi masyarakat dengan upaya mengadakan sosialisasi tatap muka pemilih pemula, pemuda, perempuan, dan disabilitas namun tetap dengan memperhatikan protokol kesehatan yang berlaku. Selain itu, KPU Kota Pekalongan mengadakan lomba menulis essay dan talkshow serta webinar kepemiluan yang dilaksanakan secara daring dengan mengandalkan media online seperti official account KPU Kota Pekalongan, Zoom Meeting, dan Youtube. Hal ini dilaksanakan untuk meningkatkan partisipasi masyarakat yang mana pada Pilkada 2015 hanya mencapai 73,42\%. Sedangkan untuk KPU Kabupaten Pekalongan, dengan terget partisipasi masyarakat 78\% dalam Pilkada 2020, melaksanakan strategi peningkatan partisipasi masyarakan dengan mengadakan workshop online Pilkada, sosialisasi keliling dengan menerapkan protokol kesehatan, sosialisasi melalui media cetak, dalam dunia pendidikan melaksanakan bekerjasama dengan guru PPKn untuk memberikan 
edukasi kepemiluan terhadap pemilih pemula, serta mengadakan talkshow kepemiluan melalui radio lokal. Hal ini dilaksanakan untuk meningkatkan partisipasi masyarakat Kabupaten Pekalongan yang mana pada Pilkada 2015 hanya mencapai 70\%. KPU Kota Semarang, dengan terget partisipasi masyarakat 77,5\% dalam Pilkada 2020, melaksanakan strategi dengan mengadakan sarasehan, virtual roadbike, sosialisasi melalui relawan demokrasi, dan melaksanakan media gathering. Hal ini dilaksanakan untuk meningkatkan partisipasi masyarakat Kota Semarang yang mana pada Pilkada sebelumnya yaitu tahun 2015 hanya mencapai 65,43\%. Hal tersebut berbeda dengan KPU Kabupaten Semarang yang memiliki target sama dengan KPU Kota Semarang yaitu 77,5\% namun lebih memfokuskan strategi meningkatkan partisipasi masyarakat dengan mengadakan sosialisasi. Sosialisasi dilaksanakan di Lapas II A Ambarawa, sosialisasi dengan pemilih difabel, dan sosialisasi pemilih perempuan. Tentunya sosialisasi tatap muka tersebut tetap dengan memperhatikan protokol kesehatan. Pada Pilkada tahun 2015, tingkat partisipasi di Kabupaten Semarang mencapai 69,99\%. KPU Kota Magelang dengan target partisipasi yang cukup tinggi yaitu $80 \%$ melaksanakan strateginya dalam bentuk media gathering. Hal ini dilaksanakan untuk meningkatkan partisipasi masyarakat Kota Magelang yang mana pada Pilkada sebelumnya yaitu tahun 2015 sudah cukup tinggi yaitu mencapai 75,23\%. Berbeda dengan KPU Kota Magelang, tingkat partisipasi masyarakat Kebumen pada Pilkada tahun 2015 hanya mencapai 64,75\%. KPU Kabupaten 
Kebumen melaksanakan strateginya dengan mengadakan sosialisasi bersama organisasi masyarakat komunitas khusus, ormas kepemudaan, ormas keagamaan, komunitas disabilitas, kelompok perempuan, dan komunitas milenial. Serta mengadakan publikasi pelaksanaan Pilkada 2020 dengan mobil keliling. KPU Kota Kebumen memiliki target partisipasi sebesar 77,5\% pada Pilkada tahun ini. KPU Kabupaten Rembang memiliki target partisipasi sebesar 77,5\%. Untuk mencapai target tersebut strategi yang dilakukan KPU Kabupaten Rembang adalah dengan mengadakan media gathering berbagai media cetak, elektronik, dan online untuk mempublikasikan informasi-informasi mengenai Pilkada 2020. Sementara untuk KPU Kota Surakarta yang memiliki target partisipasi yang sama dengan KPU Kabupaten Rembang yaitu 77,5\%, memilih strategi meningkatkan partisipasi masyarakat dengan mengadakan kegiatan Gerak Pasti yaitu tim penggerak partisipasi. Tim ini dibentuk untuk melaksanakan sosialisasi tahapan pemilu, cara menggunakan hak pilih di masa pandemi, dan memastikan masyarakat mengetahui pelaksanaan Pilkada sehingga partisipasi masyarakat untuk datang ke TPS meningkat. Hal ini berbeda lagi dengan KPU Kabupaten Purbalingga yang mana melaksanakan strategi meningkatkan partisipasi masyarakat dengan mengadakan pendekatan kepada Komunitas Kopi Purbalingga, Komunitas Petani Tanaman Hias Purbalingga, dan Komunitas Pecinta Ikan Hias Purbalingga, hal ini dilakukan karena saat pandemi masyarakat cenderung memiliki hobi baru yaitu menanam tanaman hias dan memelihara ikan hias 
sehingga dengan melakukan pendekatan terhadap kelompok tersebut sosialisasi Pilkada akan berjalan efektif. Selain itu, KPU Kabupaten Purbalingga juga mengadakan sosialisasi Pilkada bersama Forum Lintas Agama di Desa Toyareka Kecamatan Kemangkon, sosialisasi terhadap kelompok tani Ngudi Sayur Desa Kutabawa Kecamatan Karangrejo, membuat iklan layanan masyarakat, serta mengadapan RPP Live. KPU Kabupaten Purbalingga ini memiliki target partisipasi sebesar 77,5\% pada Pilkada 2020 dengan angka partisipasi pada Pilkada sebelumnya yaitu 60,06\%. KPU Kabupaten Boyolali dengan target partisipasi sebesar $77 \%$ melaksanakan strateginya dengan mengadakan sosialisasi dialog demokrasi bersama 11 basis, ngobrol santai dalam angkringan demokrasi, serta mengadakan lomba video komedi yang diikuti masyarakat Kabupaten Boyolali. KPU Kabupaten Blora dengan target partisipasi sebesar $77,5 \%$ melaksanakan strategi peningkatan partisipasi masyarakat dengan mengadakan FGD (Forum Group Discussion) bersama komunitas-komunitas yang ada di Kabupaten Blora, menggelar sarasehan bersama tokoh masyarakat Blora dan ormas Blora, serta mengadakan pertemuan dan sosialisasi dengan kelompok-kelompok tertentu. Untuk KPU Kabupaten Kendal dengan target partisipasi sebesar $\mathbf{7 7 \%}$ melaksanakan strateginya dengan mengadakan sosialisasi keliling bertema Kendal Memilih, sosialisasi secara langsung ke daerah terpencil yang kurang akses informasi, sosialisasi melalui media sosial tentang tahapan Pilbup 2020, mengadakan workshop media center, mengadakan webinar, serta 
sosialisasi tentang pencegahan klaster baru covid-19 pada penyelenggaraan Pilkada tahun 2020. Sementara, KPU Kabupaten Sukoharjo melaksanakan strategi meningkatkan partisipasi masyarakat dengan penyebaran dan pemasangan bahan sosialisasi melalui selebaran, merchandise (buku, masker, gantungan kunci, bottle, handsanitizer, masker, payung), baliho, dan spanduk. Selain itu, KPU Kabupaten Sukoharjo mengadakan temu media dan netizen dari berbagai kalangan, mengadakan sosialisasi berbasis RT atau paguyuban atau kelompok masyarakat, membuat iklan sosialisasi di media elektronik, membuat vlog atau film pendek, komik, mural, serta mengadakan webinar tentang Pilkada 2020. KPU Kabupaten Wonosobo dengan target partisipasi sebesar $74 \%$ memilih strategi menggunakan alat peraga sosialisasi dengan pendistribusian ke bawah melalui leafltet tahapan Pilkada dan informasi lainnya mengenai Pilkada 2020, membuat poster tata cara pemungutan suara saat pandemi covid-19, memasang baliho dan spanduk sosialisasi Pilkada, mengadakan talkshow melalui radio, sosialisasi melalui relawan demokrasi berjumlah 45 orang, serta mengadakan sosialisasi melalui media sosial dan media informasi lokal dilaksanakan setiap Hari Selasa dan Jumat. Sementara, KPU Kabupaten Wonogiri dengan target partisipasi sebesar $85 \%$ memilih strategi meningkatkan partisipasi dengan lebih giat lagi dalam melaksanakan upaya sosialisasi, hal tersebut dilaksanakan dengan mengadakan sosialisasi tatap muka yang memperhatikan protokol kesehatan mengenai pencalonan bersama partai politik, sosialisasi 
pelaksanaan Pilkada masa pandemi bersama masyarakat, sosialisasi melalui media massa/koran dan radio, serta mengadakan talkshow di radio lokal. KPU Kabupaten Purworejo dengan target partisipasi sebesar $77,5 \%$ melaksanakan strateginya dengan mengadakan media gathering berbagai media massa cetak, elektronik, dan online. Hal ini tidak jauh berbeda dengan strategi yang dilakukan oleh KPU Kabupaten Sragen dengan target partisipasi sebesar 77,5\%. KPU Kabupaten Sragen melaksanakan strateginya dengan mengadakan sosialisasi di tingkat PPK dan PPS 20 kecamatan dan 208 desa/kelurahan di Sragen dengan berbagai segmen seperti pemilih berkebutuhan khusus, pemilih pemula, keluarga, difabel, perempuan, dan tokoh keagamaan. KPU Kabupaten Klaten dengan target partisipasi sebesar $77,5 \%$ melaksanakan strategi meningkatkan partisipasi masyarakat dengan mengadakan FGD (Forum Group Discussion) dengan semua segment masyarakat, mengadakan sosialisasi tatap muka dengan media center, masyarakat terpencil, kaum Madinah, kaum disabilitas, serta sarasehat bersama masyarakat dan tokoh keagamaan. Selain itu, sosialisasi dilaksanakan dengan membuat video klip, iklan di koran dan radio, video pendek di media sosial KPU, serta penyebaran stiker, poster, baliho, dan spanduk di lingkungan masyarakat Klaten. Sementara, KPU Kabupaten Pemalang dengan target partisipasi sebesar 77,5\% memilih strategi peningkatan partisipasi masyarakat dengan mengadakan sosialisasi pendidikan pemilih serentak di kecamatan berbasis keluarga dan relawan demokrasi, serta mengadakan lomba 
menulis digitalisasi Pilkada yang ditujukan untuk warga net dan pemilih pemula. Berbeda dengan strategi dari KPU Kabupaten/Kota lain, KPU Kabupaten Grobogan dengan target partisipasi sebesar 77,5\% melaksanakan strategi meningkatkan partisipasi masyarakat dengan mengadakan sayembara desain maskot dan jingle Pilbup Grobogan 2020, pemasangan baliho tahapan Pilkada 2020, konser musik Terima Kasih Groboganku secara virtual, sosialisasi peraturan perundang-undangan dalam bidang politik, sosialisasi program, jadwal, dan tahapan Pilkada kepada masyarakat, sosialisasi tahapan dan pembentukan badan adhoc melalui radio Purwodadi FM, pemasangan baliho, sosialisasi keliling dengan protokol kesehatan, Ikrar damai dan menolak golput ikatan pencak silat Grobogan, dan sosialisasi Pilbup Grobogan 2020 bersama relawan demokrasi. Berbaga kegiatan tersebut merupakan bentuk semangat Kabupaten Grobogan dalam mensukseskan Pilkada serentak 2020. Dan untuk KPU Kabupaten Demak dengan target partisipasi sebesar 77,5\% pula, memilih strategi meningkatkan partisipasi masyarakat dengan membuat konten coffee morning di media massa lokal dan sosialisasi woro-woro Pilkada dengan mobil keliling.

4. Kendala yang Dihadapi dalam Melaksanakan Strategi Meningkatkan Partisipasi Masyarakat dalam Pilkada Serentak 2020 di Jawa Tengah

Dalam melaksanakan kegiatan yang berhubungan dengan strategi meningkatkan partisipasi masyarakat dalam Pilkasa 2020 tentu memiliki bergabagi macam kendala yang dihadapi apalagi kegiatan yang dilaksanakan bertepatan dengan keadaan pandemi. 
Kendala yang dihadapi dari berbagai KPU Kabupaten/Kota hamper sama, antara lain kurangnya respons masyarakat terhadap kegiatankegiatan yang dilaksanakan melalui daring atau online. Masyarakat cenderung pasif dalam merespon sehingga apa yang disampaikan belum tentu dapat diterima atau dipahami masyarakat secara keseluruhan. Hal ini memicu penurunan kualitas pemilu khususnya partisipasi masyarakat dapat berkurang di tengah pandemi. Di sisi lain, penerapan Pilkada dengan protokoler kesehatan juga membuat anggaran kebutuhan pelaksanaan Pilkada meningkat, hal ini menyebabkan anggaran untuk mengimplementasikan strategi meningkatkan partisipasi masyarakat dan upaya sosialisasi pendidikan pemilih berkurang sehingga metode yang dipilih mayoritas dilaksanakan dalam masa pandemi ini terbatas pada bentuk tatap muka melalui daring.

\section{PENUTUP}

Dari uraian di atas, dapat kita ketahui bahwa dalam Pilkada Serentak 2020, KPU memiliki target partisipasi masyarakat secara nasional sebesar 77,5\% namun, setiap Kabupaten/Kota memiliki target masingmasing. Untuk mencapai target tersebut, KPU memiliki strategi dalam meningkatkat partisipasi masyarakat. Sebelum melaksanakan strategi, terlebih dahulu KPU menentukan peran di masing-masing tingkatan KPU. KPU RI dan Provinsi berperan dalam melaksanakan strategi dengan mengadakan kegiatan yang berhubungan dengan kulit luar saja sementara KPU Kabupaten/Kota lebih mendalam dan masif. Strategi yang diterapkan 
lebih memaksimalkan sosialisasi melalui media sosial dan virtual dengan mengadakan webinar. Namun, kegiatan lain yang diadakan secara langsung atau tatap muka tetap dilaksanakan dengan syarat dan ketentuan tertentu misalnya mengurangi jumlah kegiatan dan peserta serta tetap memperhatikan protokol kesehatan.

Kendala yang dihadapi dalam menerapkan strategi meningkatkan partisipasi masyarakat antara lain kurangnya respons masyarakat terhadap kegiatan-kegiatan yang dilaksanakan melalui daring atau online. Hal ini memicu penurunan kualitas pemilu khususnya partisipasi masyarakat dapat berkurang di tengah pandemi. Kendala lain yaitu anggaran untuk melaksanakan strategi berkurang sehingga metode yang dilaksanakan dalam masa pandemi ini terbatas. 


\section{DAFTAR PUSTAKA}

Hergianasari, P. (2016). Matinya Mesin Partai Politik (Studi Kasus

Pencalonan Syahri Mulyo dalam Pilkada Kabupaten Tulungagung 2013). In Jurnal Cakrawala ISSN (Vol. 1693, Issue 2, 249). https://ejournal.uksw.edu/cakrawala/article/view/668

Hergianasari, P. (2020). Electoral Distancing: Alternatif Penyelenggaraan

Pemilihan Kepala Daerah 2020 Ditengah Covid-19 Di Indonesia.

Magistrorum Et Scholarium: Jurnal Pengabdian Masyarakat (Vol. 01,

112-121) Retrieved Agustus 1, 2020

Infografis COVID-19(1 September 2020)- Berita Terkini / Gugus Tugas

Percepatan Penanganan COVID-19. (n.d.)Retrieved September 2, 2020, from https://covid19.go.id/p/berita/ingografis-covid-19-1september-2020

Meyliana, Inggried Fena, \& Dewi Erowati. (2020). Menakar Partisipasi Politik Masyarakat Kabupaten Tana Toraja Terhadap Pemilihan Kepala Daerah (PILKADA) Tahun 2020. In Jurnal Academia Praja (Vol. 3, Nomor 2, 168). http://ejournal.fisip.unjani.ac.id/index.php/jurnal-academiapraja/article/view/183/141

Moleong, L. J. (2010). Metode Penelitian Kualitatif. Cetakan 27. Bandung: PT Remaja Rosdakarya Offset

Sniderman, P. M., \& Highton, B. (2011). Facing the challenge of democracy: Explorations in the analysis of public opinion and political participation. In Facing the challenge of democracy: Explorations in the analysis of public opinion and political participation. 